\title{
Economics of Rice Production in Wase Local Government Area of Plateau State, Nigeria
}

\author{
I. O. Ademiluyi ${ }^{1, *}$, K. I. Okeke-Agulu ${ }^{1}$, S. T. Folorunso ${ }^{2}$ \\ ${ }^{1}$ Department of Agricultural Extension and Management, Federal College of Forestry, Jos, Plateau State, Nigeria. \\ ${ }^{2}$ Department of Agricultural Economics and Extension, University of Jos, Plateau State, Nigeria.
}

How to cite this paper: I. O. Ademiluyi, K. I. Okeke-Agulu, S. T. Folorunso. (2021) Economics of Rice Production in Wase Local Government Area of Plateau State, Nigeria. International Journal of Food Science and Agriculture, 5(2), 214-218. DOI: 10.26855/ijfsa.2021.06.002

Received: February 22, 2021

Accepted: March 20, 2021

Published: April 12, 2021

*Corresponding author: I. O. Ademiluyi, Department of Agricultural Extension and Management, Federal College of Forestry, Jos, Plateau State, Nigeria. Email: bukkyinkus@yahoo.com

\begin{abstract}
The study examined the rice farmer's productivity in Wase Local Government Area of Plateau State, Nigeria; the objectives were to estimate profitability of rice farming in the study area and determine the socio economic factors affecting rice farmer's productivity. Primary data were used for this study with the aid of well-structured questionnaire. A multi-stage sampling technique was used in selecting rice farmers in the study area. Three major rice producing districts were purposely selected from the Local Government Area followed by the random selection of the villages from each districts. In all, 153 rice farmers were randomly selected from six village's. Gross margin analysis revealed that the production of rice is profitable with the gross margin of N216,576. The multiple regression estimates for determinant of productivity among rice farmers reveals that the coefficient of age, educational level and farm size were negatively significant at $1 \%$ level while the quantity of seed and fertilizer were positively significant at $5 \%$. Based on the findings of the study, recommendations are necessary for more sustainable rice production in the study area.
\end{abstract}

\section{Keywords}

Rice Farmers, Productivity and Gross-margin

\section{Introduction}

Agriculture is the mainstay of the majority of Nigerian rural poor, producing major crops comprising cereal such as sorghum, maize, rice; tubers such as yams, cassava, legume such as groundnut and cowpea as well as vegetables. Rice is cultivated in all regions of Nigeria. It ranks sixth after sorghum, millet, cowpea, cassava, and yam [1]. It accounts for about 12 percent of the total cereals produced in Nigeria [2]. Five major production systems have been identified, these are the upland rain fed, inland shallow swamp, deep water, floating lowland and irrigated rice production systems [3]. In 1990, rice yield in Nigeria was 2.07 tonnes/hectare, this reduced to as low as 1.3 tonnes/hectares in 2007 and in 2012, Nigeria rice yield was 1.88 tons/hectare [4]. The land area under rice cultivation in Nigeria in 2005 was about 2.708 million hectares. But the estimated area planted with rice in 2012 stood at 2.685 million hectares [4]. This figures indicated a reduction in area cultivated for rice over the period 2005-2012. The population growth, urbanization, profession edifice and changes in nutritional desires in Nigeria lead to an increase in the demand for rice [5], also partly owing to an increase in income [6]. Rice is a major staple food in Nigeria, but its domestic production has never been able to meet the demand $[7,8]$ observed that the demand and supply gap in rice production is widening, resulting in huge import bill on rice. Rice imports have affected the domestic production and marketing of Nigeria's local rice. This is due to the decreased demand for local rice by Nigeria as opposed to the imported ones. To increase productivity of rice farmers in the country, the government devised a policy that improves the ability of farmers to access nitrogen fertilizer, improved rice seed and extension services. Productivity is said to have increased when the rate of growth of output is faster than the growth rate of inputs used in the production [9]. Also, as a response to the prevailing rice supply deficit situation in Nigeria, successive Nigerian governments intervened in the rice sector through the establishment of paras- 
tatals and policies since 1970; all these were aimed at encouraging, boosting local rice production and enhancing strategies on food security and livelihoods of Nigerians. First, government established the Federal Rice Research Institute (NCRI) in 1974; National Seed Service (NSS) in 1975; and Operation Feed the Nation (OFN) in 1976. Other Government programmes were the River Basin Development Authority (RBDA) 1977; Agricultural Development Projects (ADP) 1975; The Structural Adjustment Programmes (SAP) 1986; [10]. The National Special Programmes on Food Security (NSPFS), National Rice Development Strategy (NRDS) 2009 and Presidential Initiative on Rice (2001), aimed at attaining food sufficiency in local production of rice in the short term (2005) and increase export in the medium term (2007), with targets of 3 million hectare cultivation, and 15 million tons of paddy rice or 9 million metric tons of rice [11]. However, despite numerous efforts and policies to increase rice farming, there has not been any significant improvement [12]. Also, Nigeria is still the world largest importer of rice [8]. In a bid to achieve rice self-sufficiency in Nigeria, a rice transformation action plan was set up in 2011 under the umbrella of the Agricultural Transformation Agenda (ATA) and the target was 6.0 million metric tons per annum of locally produced and internationally competitive milled rice by 2015 [13]. The importation of rice to bridge the demand-supply gap is worth $\$ 365$ billion [14]. The cost of these rice imports represents a significant amount of lost earnings for the country in terms of jobs and income [15]. Therefore, the main objective of the study is to analyze rice productivity among farmers in Wase Local Government Area of Plateau State, Nigeria. While the specific objective are to: estimate the cost and return of rice producers and to determine the socio-economic factors affecting rice productivity in the study area.[

\section{Methodology}

The study was conducted in Wase Local Governments Area of Plateau State, Nigeria. It is located about 216 kilometers away from Jos, the State capital, with an estimated population of 209,311 in 2015 [16]. The land covers an area of 4,587 square kilometers. The annual rainfall is $1,083 \mathrm{~mm}$ and $27.4^{\circ} \mathrm{C}$ average temperature. Major crops grown are food and cash crops as maize, sorghum, rice, groundnut, cotton, vegetables and beans. The major livestock are cattle, sheep, goat, poultry, and pigs.

A multi-stage sampling technique was conducted in three (3) district of Wase Local Government Area. The three (3) districts are Kadarko, Lamba and Wase town. The primary data in the study were obtained from 153 rice farmers. This structured questionnaire was used to collect data from the farmers during 2014/2015 season. Data were analyzed using gross margin and multiple regressions.

\section{Model Specification}

\subsection{Gross Margin Analysis}

Gross Margin is simply the difference between the total revenue and the total variable cost of each unit.

GM = TR-TVC, Where; GM = Gross Margin, TVC = Total Variable Cost, TR = Total Revenue. The variables to be used are: Seed ( $\mathrm{N} / \mathrm{kg}$ ), Fertilizer (N/Kg), Agro chemicals (N/Kg), Labour (mandays), Transportation (N/km).

\subsection{Total Factor Productivity (TFP)}

The Total Factor Productivity is measured as the inverse of the average unit cast of production. It is defined as the inverse of the ratio of total variables cost to total output. The model is approximated by a linear relationship.

\section{(i) Total Factor Productivity Model}

$$
\mathrm{TFP}=\frac{\mathrm{Q}}{\mathrm{TVC}} \text { or } \frac{1}{\mathrm{AVC}}
$$

where, TFP = total factor productivity, $\mathrm{Q}=$ output(yield) and TVC $=$ total variable cost.

$$
\begin{gathered}
\text { TFP }=\quad \mathrm{F}\left(\mathrm{Z}_{\mathrm{i}}, \mathrm{Z}_{2}, \mathrm{Z}_{3} \ldots \ldots \ldots, \mathrm{Z}_{\mathrm{m}}\right) \ldots \ldots \ldots \\
\mathrm{TFP}=\mathrm{d}_{\mathrm{o}}+\mathrm{d}_{\mathrm{i}} \mathrm{Z}_{\mathrm{i}}+\mathrm{d}_{2} \mathrm{Z}_{2}+\mathrm{d}_{3} \mathrm{Z}_{3}+\ldots \ldots \ldots+\mathrm{d}_{10} \mathrm{Z}_{10}
\end{gathered}
$$

\subsection{Multiple Regression Model}

This model was used to determine the socio economic factors influencing the productivity models (total factor). The model is as specified below:

$$
\begin{aligned}
& \mathrm{Y}=\mathrm{F}\left(\mathrm{Z}_{1}, \mathrm{Z}_{2}, \mathrm{Z}_{3}, \mathrm{Z}_{4}, \mathrm{Z}_{5}\right. \text {, ei)..... } \\
& \mathrm{Y}=\mathrm{b}_{0}+\mathrm{b}_{1} \mathrm{Z}_{1}+\mathrm{b}_{2} \mathrm{Z}_{2}+\mathrm{b}_{3} \mathrm{Z}_{3}+\mathrm{b}_{4} \mathrm{Z}_{4}+\mathrm{b}_{5} \mathrm{Z}_{5}+\text { Ui (linear) }
\end{aligned}
$$

Where $\mathrm{Z}_{1}=$ age of farmers (yrs); $\mathrm{Z}_{2}=$ level of education (yrs); $\mathrm{Z}_{3}=$ farm size (ha); $\mathrm{Z}_{4}=$ seed ( $\mathrm{N} / \mathrm{kg}$ ); $\mathrm{Z}_{5}=$ fertilizer $(\mathrm{N} / \mathrm{kg}) ; \mathrm{Z}_{6}=$ labour (mandays); $\mathrm{u}=$ error term; $\beta$ = parameters to be estimated. 


\section{Results and Discussion}

\subsection{Gross Margin Analyses of Respondents}

The result in total variable cost consist of seed, labour, fertilizer, chemicals, transportation, land rent, the total variable cost stood at N179,424. Gross Income was N 396,000 and the gross margin was N 216,576, while the return per naira increased was 0.83 (Table 1). This means that for every one naira invested, there was a return of 0.83 kobo. This implies that production of rice is profitable in the study area. This means that the income generated would help farmers to have a sustainable livelihood.

Table 1. Gross Margin of Rice Productivity in the Study Area

\begin{tabular}{|c|c|c|}
\hline Items & Cost/ha( & Percentage \\
\hline A: Gross Income (GI) & 396,000 & \\
\hline \multicolumn{3}{|l|}{ B: Variable Cost (VC) } \\
\hline Seed & 9,600 & 5.4 \\
\hline Fertilizer & 32,000 & 17.83 \\
\hline Agro chemicals & $8,752.90$ & 5.0 \\
\hline Transportation & 9,750 & 5.4 \\
\hline \multicolumn{3}{|l|}{ Labour } \\
\hline Weeding & 16,500 & 9.19 \\
\hline Harvesting & 11,540 & 6.4 \\
\hline Land preparation & 40,000 & 22.29 \\
\hline Sowing/plating & 8,350 & 4.65 \\
\hline Processing and storage & $33,431.40$ & 18.6 \\
\hline Land & 10,000 & 5.6 \\
\hline Total variable cost (TVC) & 179,424 & $100 \%$ \\
\hline C:GrossMargin (GM) & 216,576 & \\
\hline D: Net Return (NR) & 0.83 & \\
\hline
\end{tabular}

Source: Field survey, 2016.

\subsection{Socio Economic Factors Affecting Rice Farmer's Productivity in the Study Area}

The multiple regression shows that $\mathrm{R}^{2}$ (the coefficient determination) was 0.645 (Table 2). This shows that the variation in the dependent variable $\mathrm{Y}$ (output) was influenced by the combined effects of the independent variable $\left(\mathrm{z}_{1}-\mathrm{Z}_{6}\right)$. This implies that $36 \%$ of the variation in rice productivity was accounted for by the inputs included in the model.

Age: This variable is negatively significant at 5\% level. This implies that an increase in the age of the farmers would lead to a decrease by the value of -0.584 . This support the finding of [17] and [18] which found that age has a negative influence on productivity.

Educational level: This variable is negatively significant at 5\% level. This implies that an increase in the education of the farmers would lead to a decrease by the value of -0.426 . This support the finding of [17] which found that education has a negative influence on productivity.

Farm size: The variable is negatively significant at 5\% level. This implies that an increase in the farm size would lead to a decrease by the value of -0.604 .

Quantity of seed: The variable has a positive coefficient (0.114) and significant at $1 \%$ level. This implies that a unit increase of input will lead to an increase in output. This suggests that the more use of certified seed the more productive the rice farmer.

Quantity of fertilizer: This variable has a positive coefficient (0.664) and significant at 1\% probability level. This implies that the higher the use of fertilizer the more productive the rice farmer become. This support the finding of [19] which observed that the use of fertilizer increased agricultural productivity of crop farming in the dry savannah and humid forest agro-ecological zones of Nigeria. 
Table 2. Multiple Regression Rice Productivity in the Study Area

\begin{tabular}{cccc}
\hline Variables & Coefficient & Standard error & t- ratio \\
\hline Constant & 0.395 & 0.461 & 0.856 \\
Age & -0.584 & 0.226 & $-2.464^{* *}$ \\
Education & -0.426 & 0.189 & $-2.25^{* *}$ \\
Farm size & -0.604 & 0.297 & $-2.023^{* *}$ \\
Seed & 0.114 & 0.042 & $2.704^{* * *}$ \\
Fertilizer & 0.664 & 0.232 & $3.136^{* * *}$ \\
Labor & 0.635 & 0.529 & $-1.200^{\mathrm{NS}}$ \\
$\mathrm{R}^{2}$ & 0.645 & & \\
\hline
\end{tabular}

Notes: **_-5\%, ***_-1\%, NS-Non-Significant.

\section{Conclusion/Recommendations}

On the basis of findings, it was concluded that rice production in Wase Local Government Area of Plateau State is profitable given improved seed, available climate and soil requirement. It was recommended that more revenue can be made by farmers if availability of agricultural inputs are subsidized which could help them to have a sustained livelihood.

\section{References}

[1] Central Bank of Nigeria. (2003). Annual Report and Statement of Accounts, Abuja, Nigeria: CBN Publication.

[2] Central Bank of Nigeria. (2004). Annual Export and Statement of Accounts. Abuja, Nigeria; CBN Publication. Economics, University of Ibadan.

[3] Olayemi, J. A. (1997). The Nigerian Rice Industry: Performance, Problems and Prospects. A Research Report Prepared for Food and Agriculture Organization, FAI; December, 1997.

[4] Food and Agricultural Organization (FAO). (2013). Food and Agriculture Organization of the United Nations, ROME. Access date, April 22, 2013.

[5] Tanaka, A., Johnson, J. M., Senthilkumar, K., Akakpo, C., Segda, Z., Yameogo, L. P., Sarta, K. (2017). On-Farm Rice Yields and its Association with Biophysical Aacts in sub-Saharan Africa. European Journal of Agronomy, 85(1-11).

[6] Uduma, B. U., Samon, O. A., Mure, U. A. (2016). Irrigation Potentials and Rice Self-Sufficiency in Nigeria. A Review. African Journal of Agricultural Research, 11(5), 298-309.

[7] Food and Agricultural Organization (FAO). (1999). Women in Rice Farming Systems. Focus on Sub-Saharan Africa. Women in Agriculture Organization of the United Nations Rome, p. 19.

[8] Food and Agricultural Organization (FAO). (2006). Food and Agricultural Organization Year Book. Food and Agriculture Organization, Rome, Italy. P. 79.

[9] Tanko, Y., Kang, C. Y., and Islam, R. (2019). Mismanagement of the Available Irrigation Potentials of Rice Farming in Kano State, Nigeria. Asian Journal of Multidisciplinary Studies, 7(5), 28-37.

[10] Bamidele. F. S., O. O. Abayomi, and O. A. Esther. (2010). Economic Analysis of Rice Consumption Patterns in Nigeria. Journal of Agricultural Science Technology. Vol. 12, pp. 1-11.

[11] Federal Ministry of Agriculture and Water Resources (FMAWR). (2008). Nigeria’s National Food Security Programme Federal Ministry of Agricultural and Water Resources, Abuja, Nigeria, pp. 3 \& 7.

[12] Oumaroa, B. and Zhou, H. (2016). Technical Efficiency of Rice Farming in South-Western Niger: A Stochastic Frontier Approach. Journal of Economics and Sustainable Development, Vol. 7, No. 24.

[13] Federal Ministry of Agriculture and Rural Development. (2012). Rice Transformation Team: Achievements up to Date.

[14] Ayanwale, A. B. and Amusan, C. A. (2012). Gender Analysis of Rice Production Efficiency in Osun State. Implication for the Agricultural Transformation Agenda. Paper Presented at the $13^{\text {th }}$ National Conference of the Nigerian Association of Agricultural Economist, Obafemi Awolowo University, Ile-Ife, Nigeria, September $25^{\text {th }}-27^{\text {th }}$.

[15] Bamba, I., Diagne, A., Manful, J., and Ajayi, A. (2010). Historic Opportunities for Rice Growers in Nigeria. Grain de sel. No. 51, July-September 2010.

[16] NPC. (2006). National population Census. National Population Commission, Abuja, Nigeria. 
[17] Adeoti, A. I. (2002). Economic Analysis of Irrigation and Rain-Fed Production Systems in Kwara State, Nigeria. Unpublished PhD Thesis, Department of Agricultural Economics, University of Ibadan.

[18] Obasi, P. C., Henri-Ukoha A., Ukewuihe I. S., and Chidiebere-Mark, N. M. (2013). Factors Affecting Agricultural Productivity among Arable Crop Farmers in Imo State, Nigeria. American Journal of Experimental Agriculture.

[19] Ogundele, O. O. and Okoruwa, V. O. (2006). Technical Efficiency Differentials in Rice Production Technologies in Nigeria. AERC Research Paper, 154 African Economic Research Consortium, Nairobi, Kenya. 